\title{
PENGUASAAN MURID TENTANG PENGGUNAAN IMBUHAN MeN-, di- DAN BeR- DALAM PENULISAN KARANGAN RESPONS TERBUKA
}

Students' Mastery of MeN-, di- and BeR-Affixations

in Open Response Essay Writing

${ }^{1}$ ANNE JEFFREY KIHOB

${ }^{2}$ SAIDATUL NORNIS BT HJ MAHALI

${ }^{1,2}$ Pusat Penataran Ilmu dan Bahasa, Universiti Malaysia Sabah, Jalan UMS, 88400 Kota Kinabalu, Sabah. lannejeffreyk@gmail.com,

2saidatul@ums.edu.my

Tarikh dihantar: 29 September 2021 / Tarikh diterima: 29 November 2021

\begin{abstract}
Abstrak Kata berimbuhan mudah ditemui dalam mana-mana bentuk penulisan kerana morfem imbuhan yang diimbuhkan pada kata dasar akan membentuk kata kerja aktif transitif, tak transitif dan penanda pasif bagi ayat yang dibina. Walaupun sering digunakan dalam penulisan, pengimbuhan yang tidak tepat boleh mengganggu kegramatisan bahasa Melayu standard. Berdasarkan analisis kandungan terhadap 31 teks karangan respons terbuka murid-murid tingkatan empat daripada sebuah sekolah menengah di daerah Tuaran, Sabah, didapati 27 sampel karangan melakukan kesalahan penggunaan imbuhan awalan kata kerja $m e N-$, di-, dan $b e R-$. Kelemahan penguasaan varian imbuhan awalan menyebabkan kesalahan morfologi, ejaan dan ketidakgramatisan ayat yang dibina oleh murid. Pada masa yang sama, kesan daripada kelemahan penguasaan imbuhan murid, mereka telah mencipta istilah baharu yang jelas telah melanggar peraturan tatabahasa bahasa Melayu. Oleh itu, kesalahan yang didapati tidak wajar dipandang remeh kerana hal tersebut akan menyebabkan keterbiasaan murid untuk sewenang-wenangnya menggabungkan imbuhan dengan kata dasar bahasa Melayu yang lain tanpa merujuk sistem pengimbuhan yang betul. Malahan, dikhuatiri murid akan melakukan hal yang serupa dalam bentuk imbuhan yang lain. Akhirnya, murid sendiri tidak mengetahui fungsi sebenar proses pengimbuhan. Aspek pengimbuhan merupakan nahu bahasa Melayu yang wajib dikuasai oleh murid kerana agak sukar untuk membina ayat yang tidak melalui proses penerbitan. Bagi menangani masalah penguasaan imbuhan dalam kalangan murid, latih tubi yang berterusan dan pengajaran rumus pengimbuhan perlu didedahkan kepada murid.
\end{abstract}


Kata kunci: Imbuhan, karangan respons terbuka, ketidakgramatisan ayat, analisis kandungan, rumus pengimbuhan.

Abstract It is easy to spot affixes in students' essays as they formed transitive active verbs, intransitive verbs and passive verbs in their sentences. However, wrong use of affixation could cause ungrammatical use of the standard Malay language. Based on a content analysis of 31 open response essays written by form four students from a secondary school in Tuaran, Sabah, there were errors of affixation with $\mathrm{meN}$-, di-, and beR- found in 27 essays. Improper usage of affix variants has led to morphology error, misspelling and ungrammatical sentences. The lack of knowledge on using appropriate affixes has led students to create new terms which clearly do not follow the rules of Malay grammar. The findings suggest that it should not be taken for granted as it would trigger students to bind affixes with other Malay basic words according to their wish without referring to the proper affixation system. Moreover, they may do the same to other affixes. In the end, students themselves could not figure out the function of affixation. Affixation should be mastered by students as many sentences are built from the process of combining a morpheme with other words. In order to resolve this matter, students need to be tauhght affixation formula and given continuous exercises.

Keywords: Affixes, open response essay, ungrammatical sentence, content analysis, affixation formula.

\section{PENDAHULUAN}

Buku Tatabahasa Dewan yang merangkumi rujukan morfologi dan sintaksis merupakan panduan utama yang diguna pakai bagi mempelajari nahu bahasa Melayu (Fazal Mohamed et al., 2010). Ayat yang lengkap terdiri daripada binaan beberapa kata yang dibentuk daripada proses pemajmukan, penggandaan dan pengimbuhan. Berdasarkan proses pengimbuhan, morfem kata dasar digabungkan dengan morfem imbuhan sama ada secara awalan, penyisipan, apitan atau akhiran. Oleh itu, apabila sesuatu kata dasar seperti 'besar' diimbuhkan dengan imbuhan seperti meN- atau ter-, akan terbit bentuk kata baharu dengan maksud yang berbeza seperti 'membesar' dan 
'terbesar' (Nik Safiah et al., 2015). Berdasarkan kurikulum bahasa Melayu sekolah rendah dan sekolah menengah, murid-murid sebenarnya telah didedahkan dengan konsep proses pembentukan kata yang melibatkan pengimbuhan, penggandaan dan pemajmukan (KPM, 2016; KPM, 2018; Siti Rahayu \& Sharil Nizam, 2020). Malahan, turut ditekankan bahawa jika dibandingkan dengan ketiga-tiga proses pembentukan kata tersebut, pengimbuhan adalah lebih kompleks, justeru penggunaan imbuhan yang betul dari segi bentuk dan makna haruslah dikuasai (KPM, 2016; Siti Rahayu \& Sharil Nizam, 2020). Pernyataan ini jelas menunjukkan bahawa tanpa penguasaan yang kukuh tentang proses pengimbuhan, makna sesuatu kata baharu yang diterbitkan boleh berubah dan memberi kesan pada keseluruhan ayat yang dibina.

\section{OBJEKTIF KAJIAN}

Objektif kajian ini adalah seperti berikut:

1. Menganalisis aspek kesalahan murid tentang penggunaan imbuhan awalan kata kerja meN-, di- dan beR- dalam penulisan karangan respons terbuka.

2. Menganalisis hubung kait kesalahan penggunaan imbuhan awalan kata kerja meN-, di- dan beR- dalam penulisan karangan respons terbuka dengan kegramatisan ayat.

\section{METODOLOGI}

Kajian yang dijalankan ini melibatkan tiga perkara asas, iaitu kajian kepustakaan, analisis teks karangan murid dan penulisan hasil kajian. Kajian kepustakaan dilakukan bagi membuat rujukan tentang kajian lepas yang bersesuaian dengan kajian ini. Sebuah sekolah menengah luar bandar di daerah Tuaran dipilih untuk kajian ini berdasarkan prestasi lima tahun kertas bahasa Melayu dalam peperiksaan Sijil Pelajaran Malaysia (SPM). Berdasarkan pensampelan bertujuan, sebuah kelas tingkatan empat yang dikenal pasti bermasalah dalam penulisan karangan respons terbuka oleh guru bahasa Melayu yang mengajar mereka telah dipilih dalam kajian ini. Bagi meneliti kesalahan morfologi bagi aspek imbuhan, 31 sampel karangan diteliti secara analisis kandungan untuk mengenal pasti dan 
menyenaraikan kesalahan imbuhan. Jumlah sampel karangan yang dianalisis adalah mewakili jumlah 31 orang murid dalam kelas terbabit dan hadir semasa pemberian tajuk karangan dalam kelas. Seterusnya, penulisan dan perbincangan terhadap analisis kesalahan tersebut dilakukan oleh pengkaji berdasarkan Tatabahasa Dewan Edisi Ketiga selenggaraan Nik Safiah et al. (2015) yang menjadi rujukan standard di sekolah untuk mengenal pasti kesalahan morfologi yang terdapat dalam karangan murid. Murid diberi tempoh selama 1 jam 30 minit untuk menyiapkan hasil penulisan karangan dengan panjang karangan tidak kurang daripada 350 patah perkataan mengikut skema penulisan karangan respons terbuka peringkat menengah atas yang sebenar. Tajuk karangan yang ditulis oleh murid adalah berdasarkan satu tajuk yang sama bagi setiap murid. Batasan kajian ini adalah tertumpu kepada imbuhan awalan kata kerja meN-, di-, dan beRsahaja kerana fungsi penggunaan ketiga-tiga imbuhan ini yang jelas boleh membentuk ayat transitif, tak transitif dan penanda pasif (di-) serta kerap digunakan dalam mana-mana penulisan. Oleh itu, pengkaji memilih hasil penulisan karangan respons terbuka sebagai alat kajian kerana melalui skrip penulisan, kesalahan tatabahasa dapat diteliti dengan jelas kerana kerap berlaku tanpa disedari oleh murid sendiri apabila mereka lebih tertumpu pada penyiapan penulisan karangan.

\section{KAJIAN LEPAS}

Imbuhan awalan meN- merupakan imbuhan yang paling produktif dalam nahu Melayu (Nik Safiah et al., 2015; Nurul Huda \& Nor Hashimah, 2020) kerana mempunyai empat varian dengan pengertian yang berbeza bagi kepelbagaian varian tersebut. Melalui kajian kualitatif yang dilakukan oleh Nurul Huda dan Nor Hashimah (2020), pengggunaan imbuhan meN- untuk kata nama konkrit sahaja mempunyai makna yang luas dan boleh berlaku pertindihan makna. Mereka telah merujuk kata nama konkrit sebagai kata nama tak bernyawa tetapi boleh dilihat dengan mata dan disentuh dengan jari atau bahagian badan yang lain, dihidu dan didengari. Sekiranya penahu terdahulu telah mentakrifkan imbuhan awalan meN- yang bergabung dengan kata nama konkrit untuk maksud 'membuat', 'menjadi seperti', 'mengambil akan keadaan', 'berkeadaan', 'menuju sasaran', dan 'berlaku menyerupai sesuatu', mereka pula mendapati pengertian tersebut boleh menyebabkan 
pertindihan makna. Kesannya, pengguna bahasa Melayu sendiri akan menjadi keliru untuk konsep dan aspek yang sebenarnya sama sahaja. Nurul Huda dan Nor Hashimah (2020) juga telah meneliti bahawa makna kiasan paling kerap ditemui untuk imbuhan awalan meN- iaitu sebanyak 774 data. Misalnya, kata 'menggunung' mempunyai pelbagai bentuk logik untuk maksud menjadi seperti, mengambil akan keadaan, seperti, berkeadaan, ataupun menyerupai sesuatu. Oleh itu, dari perspektif yang berbeza, mereka berpendapat terdapat cara untuk menjadikan pengimbuhan $m e N$ - lebih mudah difahami tanpa pertindihan maksud iaitu dengan teori Relevans menggunakan hanya kata preposisi 'seperti' bagi maksud kiasan perbandingan yang eksplisit. Sebagai contoh, kata 'menggunung' dapat ditulis sebagai '...hujan lebat adalah lumrah malah ada ketikanya ombak tinggi seperti gunung sehingga lima meter'.

Dalam kajian secara kualitatif dan kuantitatif yang dilaksanakan oleh Amirra Shazreena dan Vijayaletchumy (2019), isu penguasaan imbuhan dalam kalangan murid terutama penutur kedua bahasa Melayu, didapati mudah berlaku. Murid tidak memahami konsep peluluhan dan penambahan huruf apabila sesuatu kata dasar digabungkan dengan imbuhan tertentu. Misalnya, murid menggunakan kata 'menysapu' walhal perkataan terbitan yang betul apabila kata 'sapu' digabungkan dengan imbuhan meNsepatutnya menjadi 'menyapu' iaitu pengguguran huruf ' $y$ '. Demikian juga untuk kata 'lap' yang diimbuhkan dengan awalan meN- sepatutnya menjadi 'mengelap' dengan varian 'menge-'. Namun, murid menjadikan kata 'mengelap' sebagai 'menlap'.

Di Malaysia, penggunaan pelbagai bahasa bukanlah satu fenomena asing lebih-lebih lagi dalam kalangan masyarakatnya yang terdiri daripada pelbagai bangsa. Ang dan Che Radiah (2012) menyifatkan seperti kaum lain di Malaysia, etnik Cina juga masih mengekalkan ciri kebudayaan mereka termasuklah penggunaan bahasa ibunda, justeru mereka menjangkakan murid Cina menghadapi kesukaran dalam penguasaan bahasa Melayu. Hal ini terbukti melalui masalah murid Cina dalam aspek sebutan, pemahaman dan juga penulisan. Masalah penulisan yang dihadapi adalah berkaitan dengan penggunaan bahasa dan penyampaian maksud yang lengkap. Sebanyak 9 peratus responden bermasalah dalam penggunaan imbuhan dan 
binaan ayat. Sungguhpun penelitian Ang \& Che Radiah berfokus kepada murid etnik Cina, senario ini boleh menjadi petunjuk pada pengkajian bahasa Melayu bahawa penutur kedua bahasa Melayu mudah berhadapan dengan kesukaran untuk menguasai bahasa kebangsaan negara. Kelemahan dalam penguasaan bahasa Melayu boleh menurunkan tahap keyakinan dan minat mereka untuk mempelajari bahasa Melayu. Oleh hal yang demikian, kesukaran yang dihadapi oleh penutur kedua bahasa Melayu wajar dikenal pasti dan dibimbing oleh guru-guru bahasa Melayu.

Siti Rahayu dan Sharil Nizam (2020) turut berpendapat murid yang mempelajari bahasa Melayu sebagai bahasa kedua lebih bermasalah dalam penguasaan tatabahasa. Kesalahan tatabahasa seperti imbuhan banyak didapati dalam penulisan karangan. Melalui penelitian mereka terhadap hasil karangan bahasa Melayu murid-murid Cina, kesalahan imbuhan yang dianalisis adalah meliputi penggunaan imbuhan awalan kata kerja meN- dan imbuhan awalan di-. Bagi kesalahan imbuhan awalan kata kerja meN-, contoh kesalahan yang didapati dalam ayat yang ditulis oleh murid ialah, 'Pakaian kotor memsebabkan kita bau busuk'. Kemudian, dalam ayat 'baju yang di cuci berbau wangi' dan 'sabun perlu diletakkan di tempat yang selamat' menunjukkan kekeliruan murid akan fungsi sebenar penggunaan kata 'di' sebagai imbuhan penanda pasif atau sebagai kata sendi nama. Sebenarnya, imbuhan awalan kata kerja merupakan kesalahan tatabahasa yang kerap dilakukan oleh murid dalam pembelajaran bahasa Melayu seperti yang telah dibuktikan dalam kajian terdahulu oleh Alhaadi dan Zaitul Azma Zainon (2018). Kesalahan imbuhan kata kerja yang dilakukan oleh murid pula masih melibatkan penggunaan imbuhan awalan 'di-' dan 'meN-'. Sebagai contoh, kata 'di tempat' ditulis sebagai 'ditempat' dan 'dibasuh' dieja sebagai ‘di basuh'. Selaras dengan kajian Siti Rahayu dan Sharil Nizam (2020), kekeliruan tersebut turut menyebabkan murid tidak mengeja dengan betul untuk keadaan yang memerlukan kata yang digandingkan dengan alomorf dieja serangkai atau sebaliknya. Malahan dalam penggunaan imbuhan $m e N-$, masih ada murid menulis 'menyebabkan' sebagai 'mensebabkan'. 
Penelitian Zaharani dan Teressa (2010) yang menumpukan penguasaan bahasa Melayu murid dari aspek pengimbuhan dan ejaan mendapati bahawa penguasaan mereka dalam kedua-dua aspek ini berada pada tahap kurang memuaskan. Berdasarkan skor yang diperoleh, penguasaan murid dalam imbuhan dan ejaan hanyalah sebanyak 56.9 peratus. Dari aspek imbuhan, murid menunjukkan kesukaran untuk membina ayat yang menunjukkan maksud 'bermuka-muka'. Murid menyangka 'bermuka-muka' membawa maksud banyak, sedangkan dalam konteks pragmatik, kata 'bermuka-muka' bererti 'berpura-pura'. Contoh kesalahan ayat yang ditulis oleh murid ialah 'buku itu mempunyai muka surat yang bermuka-muka'. Seterusnya, murid tidak dapat membezakan maksud 'kemasyarakatan' dengan 'memasyarakatkan' seperti dalam ayat 'Gerakan Cintailah Bahasa Kita telah dilancarkan untuk mendukung usaha kemasyarakatan bahasa Melayu' . Sepatutnya kata 'kemasyarakatan' diganti dengan 'memasyarakatkan' bagi membawa maksud sesuatu perbuatan. Bagi kesalahan ejaan pula, murid masih tidak dapat membezakan ejaan kata sendi nama 'di' dengan imbuhan pasif ‘di'. Misalnya, 'dipantau' dieja sebagai 'di pantau'. Penelitian Zaharani dan Teresa menyimpulkan bahawa murid perlu tahu akan maksud pragmatik seperti kata 'bermuka-muka' dan nahu praktis di sekolah.

Selanjutnya, Agustina Putri Reistanti (2017) menyatakan, sebagai satu bentuk komunikasi yang tidak memerlukan penulis bersemuka dengan pembaca, kegiatan menulis diakui merupakan aktiviti yang produktif dan ekspresif. Pada masa yang sama, kemahiran menulis bukanlah dimiliki sejak lahir tetapi boleh dipelajari melalui latihan yang berterusan. Dalam penelitian yang dijalankan oleh beliau untuk kesalahan dalam bidang morfologi, terdapat kata yang sepatutnya diimbuhkan dengan beR-ditulis dengan imbuhan ke-. Contohnya, kata 'ketemu' ditulis sebagai 'bertemu'. Bagi kesalahan kata di-, masih terdapat pengulangan cara penulisan yang salah untuk 'diatasnya' dan 'dikandang' yang sepatutnya dieja terpisah bagi kata yang menunjukkan tempat. Masalah penguasaan imbuhan dan kekeliruan penggunaan kata 'di' turut diutarakan dalam kajian Nurul Ain dan Nik Nur Athirah (2021). Dapatan kajian mereka mendapati bahawa kesalahan penggunaan imbuhan mencatat peratus kesalahan sebanyak 16.4 peratus dan merupakan jenis kesalahan ketiga yang paling banyak ditemui dalam penulisan karangan. Contoh kesalahan yang didapati ialah 
kata 'pelancongan' dalam ayat 'Sekiranya anda datang ke Malaysia untuk pelancongan, anda tidak...' sepatutnya diganti dengan kata 'melancong' dengan imbuhan meN- . Seterusnya, imbuhan awalan 'di' pula masih dieja terpisah daripada kata dasar 'pakai' kerana tidak tahu fungsi kata 'di' sebagai imbuhan awalan pasif.

Penekanan akan penguasaan aspek tatabahasa seperti pengimbuhan adalah sesuatu yang wajar kerana kecekapan dalam memahami nahu bahasa Melayu membantu murid menghasilkan penulisan yang ada hubung kaitnya dengan makna gramatikal (Nurul Adzwa et al., 2020). Berdasarkan 30 sampel karangan yang diteliti, terdapat 66 kesalahan imbuhan yang dilakukan oleh murid yang melibatkan imbuhan awalan dan imbuhan apitan. Mereka berpendapat penguasaan imbuhan murid adalah pada tahap lemah dan sederhana. Berbanding dengan kata nama dan kata adjektif, pengimbuhan untuk golongan kata kerja telah mencatat jumlah kesalahan yang tertinggi iaitu sebanyak 62.1 peratus. Bentuk kesalahan imbuhan awalan kata kerja yang didapati adalah melibatkan awalan di-, ber- dan $m e N-$ . Sebagai contoh, murid menggunakan imbuhan awalan 'ber-' dalam kata dasar 'minum' dalam ayat 'Antaranya ialah menghisap rokok, berminum arak dan menagih dadah', sedangkan imbuhan yang paling tepat sepatutnya ialah 'meN-'. Selanjutnya, dalam kesalahan imbuhan apitan kata kerja, contoh kesalahan yang diteliti ialah penambahan imbuhan akhiran yang tidak perlu dalam kata terbitan 'diambilkan' iaitu 'nasi dan bijirin merupakan makanan karbohidrat yang perlu diambilkan dengan banyak dalam setiap hari'. Jelaslah, ketidakcekapan pengimbuhan telah menyebabkan makna gramatikal ayat yang ditulis telah terganggu. Para pengkaji ini turut menyatakan bahawa faktor-faktor yang menyebabkan murid melakukan kesalahan imbuhan ialah murid tidak memahami perubahan makna yang berlaku dalam sesebuah ayat apabila melibatkan pengimbuhan. Oleh itu, mereka turut menekankan bahawa jika murid tahu proses pengimbuhan, mereka juga akan mengetahui fungsi serta perubahan makna yang berlaku selepas mengimbuhkan sesuatu kata dasar. Dengan demikian, murid berupaya menggunakan imbuhan mengikut kesesuaian dari konteks makna gramatikal serta dapat membina ayat yang ada kesatuan makna. 
Berdasarkan ujian karangan terhadap sepuluh orang pelajar tingkatan enam, Ahmed Hafizainol dan Karim (2020) berpendapat bahawa murid terpengaruh dengan bahasa ibunda mereka dan tidak memahami fungsi penggunaan sesuatu imbuhan. Akibatnya, kata yang ditulis dalam penulisan formal menjadi tidak gramatis. Mereka mendapati terdapat kesalahan morfologi yang tinggi untuk penggunaan imbuhan awalan meN- dan beR- iaitu masing-masing sebanyak 44.4 peratus. Murid cenderung menggugurkan penggunaan imbuhan $m e N$-dan beR-dalam ayat yang ditulis. Antara contoh kesalahan yang direkodkan ialah, '... pergi main badminton dengan kawannya' dan 'buat amal ibadah dan baca Quran...'. Dalam keduadua ayat tersebut, kata 'main', 'buat' dan 'baca' tidak dibubuhkan dengan imbuhan $m e N$ - dan $b e R$ - supaya menjadi kata yang lebih tepat istilahnya iaitu 'bermain', 'membuat' dan 'membaca'.

Nor Hashimah, Junaini dan Zaharani (2010) pernah menyuarakan kebimbangan dalam kajian mereka bahawa murid masih sukar menguasai bahasa Melayu dengan baik walaupun sudah bertahun-tahun bahasa Melayu diiktiraf sebagai bahasa pengantar di sekolah dan menjadi mata pelajaran wajib. Mereka berpendapat sikap dan persepsi murid terhadap bahasa Melayu perlu diubah sebelum peminggiran bahasa Melayu menjadi lebih sukar dibendung pada masa akan datang. Berpandukan kajian lepas, kelemahan morfologi boleh terjadi terhadap mana-mana pembelajar bahasa Melayu tanpa mengira latar belakang dan tingkat pendidikan mereka. Apabila penguasaan morfologi murid kurang mantap, mereka akan menulis mengikut kefahaman mereka tanpa menyedari perlanggaran nahu bahasa Melayu yang berlaku. Akhirnya, mereka semakin tidak dapat membezakan penggunaan bahasa Melayu yang standard dengan bahasa pasar (Siti Rahayu \& Sharil Nizam, 2020). Fenomena sebeginilah yang perlu dielak jika martabat bahasa Melayu mahu terus dilestarikan.

\section{DAPATAN KAJIAN}

Sebanyak 27 daripada 31 sampel karangan yang diteliti melakukan kesalahan imbuhan awalan kata kerja iaitu meN-, di-, dan beR-. Daripada jumlah tersebut, 11 sampel karangan melakukan kesalahan imbuhan meN, tujuh sampel karangan melakukan kesalahan imbuhan beR- dan sembilan sampel karangan melakukan kesalahan imbuhan di-. 
Bagi kesalahan imbuhan meN-, contoh kesalahan imbuhan yang dilakukan oleh murid adalah seperti berikut:

1. Telefon bimbit membawa kepentingan kepada kalangan remaja yang memakses maklumat mengenai pelajaran, isu semasa dan ramalan cuaca.

2. Contoh-contoh kesan negatif yang terdapat di dalam telefon bimbit ialah seperti gambar-gambar yang tidak sesuai, memain permainan video secara berlebihan...

3. Remaja tangguh kerja rumah mereka yang diberi oleh guru.

4. Inilah akibat remaja sekolah tidak merasa sihat kerana tidak cukup rehat...

5. Mamanya budak itu telah membawa ke Klinik Tuaran mencheck...

Bagi kesalahan imbuhan beR-, contoh kesalahan imbuhan yang dilakukan oleh murid adalah seperti berikut:

1. Kita boleh berhubung dengan keluarga atau kawan yang bertinggal di tempat lain...

2. Ada juga pelajar lewat datang ke sekolah kerana bermain games sehingga lewat malam, sebagai contoh pelajar bermain games tanpa berhenti kerana terlalu seronok bermain games.

3. ...kita harus berbijak memikir.

4. Pada pendapat saya, telefon bimbit ialah alat berhubung yang canggih pada zaman ini.

5. Kegunaan gajed penting bagi remaja untuk berkomunikasi seperti berwhatsapp...

Bagi kesalahan imbuhan di-, contoh kesalahan imbuhan yang dilakukan oleh murid adalah seperti berikut:

1. Selain daripada penyakit, jika kita bermain gajet ini sambil di cas...

2. Kita boleh juga membuat panggilan-panggilan kecemasan dan $\boldsymbol{d i}$ jawab dengan cepat oleh zaman telefon bimbit yang terkini ini.

3. Disamping itu, telefon bimbit ini juga penting untuk berkomunikasi dengan saudara yang jauh...

4. Ia merupakan sebuah alat yang kita boleh bawa dimana-mana sahaja. 
5. Selain itu terdapat beberapa kepentingan menggunakan telefon bimbit seperti mencari maklumat yang penting yang diminta oleh guru-guru disekolah.

\section{Perbincangan Hasil Dapatan}

Dalam kajian ini, perkara yang dapat diteliti ialah adanya kelemahan penguasaan penggunaan imbuhan murid yang melibatkan konteks 'perbuatan' iaitu golongan kata kerja dalam penulisan karangan respons terbuka. Oleh itu, kajian ini juga telah mencapai objektif yang diteliti melalui analisis kandungan karangan iaitu murid masih bermasalah tentang penggunaan imbuhan awalan kata kerja meN-, di- dan beR-. Kemudian, kelemahan penguasaan imbuhan awalan tersebut juga jelas telah mengganggu binaan ayat yang gramatis.

\section{Aspek Kesalahan Imbuhan meN-}

Nik Safiah et al. (2015), telah menjelaskan bahawa terdapat empat bentuk varian bagi awalan $m e N$ - yang membentuk kata kerja aktif iaitu me-, mem-, men-, dan meng-. Perubahan varian yang berlaku pula bergantung kepada huruf pertama kata dasar yang mahu diimbuhkan dengan varian meN-. Dalam ayat pertama, kata dasar 'akses' yang diimbuhkan, sepatutnya menerima varian meng- kerana huruf pertama kata dasar ialah bunyi vokal 'a'. Oleh itu, memakses perlu diubah menjadi mengakses. Dalam ayat kedua, kata terbitan memain adalah lebih tepat dengan penggunaan imbuhan awalan kata kerja beR- bagi membentuk kata kerja tak transitif berpelengkap. Berdasarkan penelitian terhadap penulisan karangan respons terbuka murid, mereka lazimnya menulis ayat dalam bentuk ayat aktif dan ayat pasif.

Menurut Nik Safiah et al. (2015), kata kerja transitif diikuti dengan objek atau penyambut bagi kata kerja. Oleh itu, dalam ayat 'Remaja tangguh kerja rumah mereka yang diberi oleh guru', kata 'tangguh' sewajarnya diimbuhkan dengan imbuhan meN- untuk diterbitkan menjadi menangguh. Kemudian, bagi kata 'merasa', seperti yang telah dinyatakan, varian $m e N$ berubah mengikut huruf pertama kata dasar. Dalam hal ini, pengimbuhan kata dasar 'rasa' dengan varian me- masih betul kerana huruf pertama kata dasar 'rasa' bermula dengan $r$. Walau bagaimanapun, ayat tersebut bersifat 
tak transitif berpelengkap dengan kata 'sihat' sebagai pelengkap untuk kata kerja 'rasa'. Oleh itu, dari aspek konteks ayat yang mahu disampaikan oleh murid, kata 'rasa' sepatutnya diterbitkan menjadi 'berasa'. Keadaan ini diterangkan lebih lanjut dalam bahagian perbincangan yang melibatkan kegramatisan ayat. Seterusnya, dalam ayat kelima, varian meN- telah dicantumkan dengan kata bahasa Inggeris check menjadi 'mencheck'. Jelas sekali berlaku pelanggaran nahu bahasa Melayu kerana tidak ada kata bahasa Inggeris diimbuhkan dengan morfem bahasa Melayu. Sebagai cadangan supaya tidak menyalahi nahu bahasa Melayu, murid boleh menggunakan frasa 'pemeriksaan kesihatan' bagi maksud 'mencheck' di pusat kesihatan.

\section{Aspek Kesalahan Imbuhan beR-}

Berbeza dengan varian meN-, semua huruf yang mendahului kata dasar boleh dicantumkan dengan awalan beR- (Ismail, 2017). Perkataan yang menerima awalan $b e R$ - memberi pengertian seperti dalam Jadual 1.

Jadual 1 Pengertian imbuhan beR-

\begin{tabular}{|lll|}
\hline \multicolumn{1}{c}{ Bil. } & \multicolumn{1}{c}{ Pengertian Imbuhan beR- } & Contoh Perkataan \\
\hline 1 & Melakukan perbuatan seperti yang terkandung dalam kata dasar & Berundur \\
2 & Refleksif & Berhias \\
3 & Perbuatan bersalingan & Berkelahi \\
4 & Keadaan yang sudah sedia berlaku & Berjahit \\
5 & Mempunyai & Beristeri \\
6 & Memakai atau menggunakan & Berbedak \\
7 & Mengusahakan sesuatu & Bersawah \\
8 & Menghasilkan & Berbuah \\
9 & Meminta bantuan & Berguru \\
10 & Berada dalam sesuatu keadaan & Berduka \\
11 & Memperoleh & Beruntung \\
12 & Menunjukkan bilangan & Berdua \\
13 & Bersama-sama & Berserta \\
\hline
\end{tabular}

Sumber: Tatabahasa Dewan Edisi Ketiga (2015)

Berdasarkan konteks ayat pertama, berlaku pengimbuhan ber- pada kata dasar 'tinggal' yang tidak merujuk mana-mana pengertian dalam Jadual 1. Hal ini menyebabkan perubahan maksud dalam ayat yang ditulis kerana 'bertinggal' seperti yang ditakrifkan dalam Kamus Dewan membawa makna 'berpesan' seperti dalam frasa 'bertinggal kata'. Oleh itu, kata 'tinggal' lebih 
sesuai tidak diimbuhkan dengan morfem $b e R$-. Demikian juga dalam ayat kedua, frasa 'bermain games tanpa berhenti' memadai jika kata 'main' sahaja yang diimbuhkan tanpa mengubah kata 'henti' bagi menunjukkan perbuatan refleksif. Kemudian, dalam ayat ketiga, berlaku pertindihan pengimbuhan bagi kata 'bijak' dan 'fikir' yang boleh menimbulkan kecelaruan makna dalam ayat yang ditulis. Lebih mudah sekiranya frasa 'berbijak memikir' ditulis 'bijak berfikir' bagi menekankan perbuatan berfikir dengan bijak. Selanjutnya, dalam ayat keempat, konteks ayat tersebut menekankan telefon bimbit sebagai suatu teknologi yang canggih. Oleh itu, kata terbitan 'berhubung,' sepatutnya menggunakan imbuhan apitan peR-...-an untuk membentuk kata terbitan 'perhubungan' sekali gus merujuk telefon bimbit sebagai kata nama. Ayat kelima yang mengandungi kata 'berwhatsapp' merupakan keadaan serupa yang didapati bagi kata ' mencheck' iaitu murid telah menggabungkan unsur bahasa Inggeris dengan morfem bahasa Melayu yang jelas tidak tepat penggunaannya. Pada masa yang sama, penggunaan kata 'berwhatsapp' menunjukkan murid telah terpengaruh dengan budaya bahasa media sosial yang popular seperti aplikasi WhatsApp. Mereka berpendapat populariti aplikasi ini pastinya sudah diketahui umum oleh semua orang dan berfikir cara penulisan sedemikian juga diterima dalam penulisan formal.

Dalam analisis teks penulisan yang dijalankan oleh Hasmidar, Mardian dan Puteri Roslina (2018), penggunaan imbuhan beR- adalah lebih mudah berbanding pembelajaran imbuhan yang membentuk kata kerja lain seperti meN-, MeN...kan, Memper...kan, Memper...i, di...kan. diper... dan diper...kan kerana imbuhan beR- tidak mempunyai varian morfem yang kompleks. Apa-apapun, kreativiti dan inovasi guru dalam merancang strategi pengajaran dan pembelajaran bagi menangani masalah penguasaan imbuhan dalam kalangan murid-murid perlu ditekankan kerana mereka merupakan golongan profesional yang lebih tahu kekangan bahasa yang dihadapi oleh anak-anak murid mereka (Yong \& Vijayaletchumy, 2012; Siti Rahayu \& Sharil Nizam, 2020). Pengajaran yang menarik diyakini dapat menjadikan pengajaran dan pembelajaran bahasa Melayu menjadi lebih berkesan dan dapat meminimakan kesalahan bahasa yang kerap dilakukan dalam penulisan karangan (Nurul Ain \& Nik Nur Athirah, 2021). Sebaliknya, pengajaran yang tidak berkesan akan menyebabkan 
murid semakin sukar menguasai aspek-aspek tatabahasa dan mereka tidak mampu menterjemahkan aspek tatabahasa dengan tepat dalam mana-mana penulisan (Nurul Adzwa et al., 2020).

\section{Aspek Kesalahan Imbuhan di-}

Serupa dengan awalan kata kerja beR-, awalan $d i$ - boleh diimbuhkan pada semua huruf yang mendahului kata dasar (Ismail, 2017). Kesalahan untuk imbuhan kata kerja di- menunjukkan kekeliruan murid dalam membezakan ejaan yang perlu diserangkaikan atau dipisahkan. Oleh itu, dapat diperhatikan bahawa masih terdapat kecenderungan murid untuk mengeja 'dicas' sebagai 'di cas' dan 'di sekolah' sebagai 'disekolah'. Nik Safiah et al. (2015) telah menggariskan dalam buku panduan Tatabahasa Dewan bahawa imbuhan awalan $d i$ - yang digabungkan dengan kata dasar, membentuk kata kerja pasif dan sepatutnya dieja serangkai dengan kata dasar. Kemudian, bentuk kata di- yang merupakan kata sendi nama pula digunakan di hadapan kata nama atau frasa nama yang menunjukkan tempat serta ditulis terpisah daripada kata nama atau frasa nama yang mengikutinya. Oleh itu, kata 'disamping itu', 'dimana-mana' dan 'disekolah' sepatutnya ditulis 'di samping itu', 'di mana-mana' dan 'di sekolah' kerana merujuk tempat atau kedudukan.

\section{Gangguan terhadap Kegramatisan Ayat}

Kesalahan penggunaan imbuhan awalan kata kerja meN-, beR- dan di- telah mengganggu kegramatisan ayat yang ditulis oleh murid. Ayat menjadi tidak gramatis kerana pemilihan morfem imbuhan yang salah dan penggabungan unsur morfem bahasa Melayu dengan kata bahasa Inggeris. Secara tidak langsung, penulisan yang formal menjadi cacamarba kerana penggunaan bahasa Melayu yang rancu.

Kajian Paul et al. (2020) pernah menyifatkan penulisan ayat murid melibatkan unsur pemindahan latihan, pengeneralisasian dan pemudahan. Secara ringkasnya, pemindahan latihan merupakan terjemahan langsung bahasa pertama murid ke dalam bahasa kedua yang dipelajari. Pengeneralisasian pula melibatkan penggunaan suatu kata dalam bahasa 
pertama yang digunakan juga dalam bahasa Melayu standard kerana berpendapat penggunaan perkataan tersebut masih betul. Contohnya, kata 'bagi' diertikan sebagai 'beri', manakala unsur pemudahan merupakan satu keadaan murid menyingkatkan penulisan sesuatu ayat menyebabkan ayat tersebut cenderung untuk menjadi kurang lengkap atau tergantung. Oleh itu, berdasarkan ayat ketiga 'Remaja tangguh kerja rumah mereka yang diberi oleh guru', dapat dikatakan bahawa terdapat pengaruh unsur pemudahan yang bukan sahaja berlaku pada kata kerja 'tangguh' tetapi juga frasa 'remaja tangguh (penyiapan) kerja rumah'. Hal ini dikatakan demikian kerana, penyelitan kata 'penyiapan' akan melengkapkan maksud yang mahu ditekankan dalam keterangan predikat. Sesungguhnya, dalam penulisan formal seperti aktiviti menulis karangan di sekolah, pengimbuhan merupakan salah satu cara untuk memastikan penulisan murid tidak dipengaruhi oleh laras bahasa lisan. Apabila terdapat penulisan ayat seperti 'Remaja tangguh kerja rumah...' penggunaan kata 'tangguh' sudah tidak menunjukkan formaliti dalam penulisan formal. Jika dibandingkan dengan kata 'menangguh', pengimbuhan tersebut dapat memberi penekanan pada bentuk penulisan yang lebih rasmi selain menunjukkan ayat yang ditulis adalah berbentuk ayat aktif transitif dengan adanya unsur penyambut atau objek dalam ayat yang dibina. Secara tidak langsung, jika murid memahami fungsi penggunaan imbuhan, mereka juga dapat mengenali jika ayat yang ditulis merupakan ayat aktif transitif atau tak transitif, berpelengkap atau tidak berpelengkap, serta binaan ragam ayat aktif dan ayat pasif. Dengan demikian, murid juga lebih mudah menguasai peraturan tatabahasa lain dalam bahasa Melayu dan dapat membantu mereka menjawab kertas peperiksaan yang menuntut murid untuk mencari kesalahan bahasa. Pada asasnya, pengertian kata 'tangguh' masih boleh difahami dalam ayat tersebut. Namun, dalam penulisan formal, fungsi morfem bebas seperti imbuhan dapat membentuk ayat yang lebih gramatis kerana ayat yang ditulis juga merupakan ayat aktif transitif.

Selanjutnya, bagi kata 'merasa', walaupun terdapat kata terbitan merasa, tetapi murid perlu berupaya membezakan perbezaan maksud antara berasa dan merasa.Tambahan pula berdasarkan perbezaan maksud menurut Kamus Dewan Edisi Keempat, 'merasa' merujuk perbuatan mengalami rasa dengan lidah, manakala 'berasa' bermaksud mendapat rasa yang dialami oleh 
bahagian-bahagian badan. Oleh hal yang demikian, berdasarkan konteks ayat tersebut, kata terbitan 'merasa' lebih sesuai digantikan dengan 'berasa'. Demikian juga untuk kata 'bertinggal', penambahan morfem beR- tidak semestinya mendukung formaliti yang bermaksud perbuatan menginap atau duduk di sesuatu tempat. Kemudian, pertindihan imbuhan dalam frasa 'berbijak memikir' boleh menyebabkan ayat tergantung kerana ketiadaan unsur objek atau penyambut dalam ayat. Ringkasnya, penulisan sebegini hanya mendorong kepada ketidakgramatisan ayat dan kecelaruan makna kepada pembaca.

Pada masa yang sama, apabila murid tidak tahu perbezaan golongan kata yang ditulis sama ada imbuhan atau kata sendi nama, hal tersebut juga boleh menyebabkan kesalahan ejaan. Walaupun nampak remeh untuk pengejaan yang perlu diserangkaikan atau sebaliknya, keadaan ini boleh menjadi keterbiasaan kepada murid untuk sewenang-wenangnya mengeja asalkan huruf yang ditulis masih betul. Jika perspektif ini tidak diubah, murid juga tidak akan mempedulikan konsep pengejaan lain yang memerlukan sesuatu kata dieja terpisah dengan simbol '-' seperti yang terdapat dalam kata 'e-mel' dan 'k-ekonomi'. Kesannya, ketidakpekaan murid tentang penggunaan nahu bahasa Melayu yang betul akan mewujudkan pula permasalahan baharu dalam linguistik iaitu kesalahan ejaan yang tidak berkesudahan. Hal ini sebenarnya boleh diperbaik sekiranya murid boleh membuat penilaian kendiri hasil karangan mereka. Kemudian, guru-guru bahasa Melayu juga perlu kerap menerangkan kepada murid bentuk ejaan yang betul termasuklah penggunaan simbol tertentu. Dalam mana-mana penulisan formal, kesalahan ejaan sama pentingnya dengan kesalahan tatabahasa kerana kedua-duanya boleh menyebabkan impresi pembaca terhadap penulisan tersebut akan terjejas.

Kemudian, dapatan baharu yang didapati dalam kajian ini ialah adanya kecenderungan murid untuk menggabungkan kata bahasa Inggeris dengan morfem bahasa Melayu sehingga menampakkan penciptaan istilah baharu yang melanggar nahu bahasa Melayu seperti kata 'mencheck' dan 'berwhatsapp'. Keadaan ini berlaku apabila murid tidak dapat mencari padanan yang betul bagi melengkapkan ayat yang ditulis. Perkataanperkataan bahasa Inggeris yang digunakan telah berfungsi sebagai penghubung ayat agar dapat difahami oleh pembaca. Nor Hashimah dan 
Adriana Santa (2016) pernah menyatakan percampuran bahasa yang berlaku bukanlah melanggar rumus sintaksis secara total kerana ayat masih boleh difahami, malahan hal tersebut menunjukkan kekreatifan murid mengatasi masalah penggunaan istilah yang sesuai dengan melakukan percampuran bahasa. Namun demikian, terdapat garis panduan penggunaan istilahistilah asing ini iaitu kosa kata pinjaman perlu melalui penyesuaian dari pelbagai aspek serta diiktiraf penggunaannya oleh jawatankuasa yang bertanggungjawab dalam bidang kebahasaan untuk mengelak wujudnya 'bahasa rojak' (Roksana, 2015). Kecenderungan murid untuk melakukan percampuran bahasa bertepatan dengan pernyataan Mohd Syuhaidi dan Aliffluqman (2018) yang menyifatkan percampuran kod telah menjadi amalan biasa yang berlaku dalam bahasa lisan dan penulisan. Lebihlebih lagi, penggunaan media sosial seperti Twitter dan Whatsapp banyak mempengaruhi cara murid menggunakan bahasa Melayu.

Kajian oleh Hidayah et al. (2019) turut mendapati penggunaan bahasa rojak dalam kalangan generasi muda banyak dipengaruhi oleh media sosial. Terdapat perbezaan yang jelas antara bentuk komunikasi lama dengan komunikasi baharu kerana masyarakat tidak perlu lagi membuka buku, majalah atau akhbar. Sebaliknya, platform seperti Youtube, laman web Yahoo, Google dan aplikasi sosial seperti WhatsApp telah mempengaruhi cara masyarakat berkomunikasi. Tidak hairanlah pengguna komunikasi baharu ini juga mudah terdedah dengan istilah-istilah moden dan nampak trending bagi menerangkan sesuatu fenomena dan situasi. Tambahan pula, dalam komunikasi maya, pengguna ialah individu aktif yang berperanan sebagai penghubung, pencipta dan kolaborator. Oleh itu, tidak mustahil sekiranya pengguna teknologi begitu cepat menerima, menyerap dan beradaptasi dengan istilah-istilah baharu yang digunakan sehingga membentuk rangkaian komunikasi yang segera difahami oleh pengguna-pengguna lain (Siti Rahimah et al., 2014). Bahkan, stesen televisyen juga kurang menitikberatkan kesan pencemaran bahasa dalam rancangan-rancangan yang diterbitkan. Hal ini ditambah lagi dengan sikap golongan selebriti yang suka menggunakan bahasa rojak menyebabkan isu bahasa rojak semakin sukar dibendung. Menurut Mohd Syuhaidi dan Nor Audra Dayana (2018), penonton akan mudah terpengaruh kerana pelakon-pelakon popular ini dianggap sebagai idola mereka. Setiap dialog yang diucapkan, kedengaran lebih 'hebat'. 
Dalam pembelajaran bahasa Melayu, Jaafar (2008) berpendapat bahawa pengajaran nahu adalah teras kepada penguasaan bahasa Melayu. Pembelajaran bahasa Melayu juga adalah lebih mudah kerana bahasa Melayu menggunakan huruf rumi yang sudah dikenali umum. Kedinamikan bahasa Melayu dibuktikan melalui penyesuaian pelbagai istilah daripada bahasa asing yang diserapkan dalam bahasa Melayu. Akhiran-akhiran dalam bahasa Inggeris seperti -ive, - al dan -ic menjadi -if, kekal -al dan menjadi -ic dalam bahasa Melayu. Akhiran lain bahasa Inggeris seperti -tion pula dialihkan menjadi -si. Bahkan, kata seperti 'ingestion' atau 'identification' dapat diimbuhkan dengan $m e N$ - dan $m e N-\ldots$-kan untuk menjadi kata kerja iaitu 'mengingesi' dan 'mengidentifikasikan'. Penggunaan morfem seperti ber-. di-kan, me- dan me-kan sememangnya kerap digunakan dalam istilah saintifik. Penyesuaian ini sentiasa berlaku dan bertambah demi memenuhi keperluan terjemahan istilah dalam pelbagai bidang. Perkara yang cuba ditekankan di sini ialah penyerapan bahasa asing khususnya bahasa Inggeris bukanlah berlaku sewenang-wenangnya. Sekiranya murid tahu asas nahu bahasa Melayu, maka mereka dapat menyesuaikan kata bahasa Inggeris yang sudah diselaraskan dalam bahasa Melayu dan bukannya mengambil terus kata bahasa Inggeris untuk digabungkan dengan morfem bahasa Melayu.

Bagi mengatasi masalah penguasaan tatabahasa murid khususnya aspek pengimbuhan, penggunaan Tatabahasa Dewan perlu ditekankan dalam pengajaran dalam kelas terutama apabila murid berada pada peringkat sekolah menengah kerana pada tahap umur tersebut, mereka sepatutnya sudah boleh memahami cara membuat rujukan daripada sumber lain. Tatabahasa Dewan merupakan panduan utama di sekolah dan sewajarnya dimaksimumkan penggunaannya kerana rujukan tersebut adalah lengkap untuk murid merujuk peraturan morfologi bahasa Melayu. Selanjutnya, pelbagai bentuk intervensi menggunakan alat bantu mengajar yang sesuai boleh diselitkan agar pengajaran tatabahasa menjadi lebih berkesan. Apa-apapun cara yang digunakan, peringkat sekolah merupakan asas pembelajaran bahasa yang dilalui oleh murid dan perlu diperkasakan. Pengajaran yang inovatif dan berkesan boleh meninggalkan kesan yang mendalam kepada murid-murid walaupun selepas mereka menamatkan zaman persekolahan. Sebagai golongan profesional yang paling rapat dengan murid, guru-guru bahasa Melayu yang mengajar mereka perlu lebih peka 
akan kesalahan morfologi yang dilakukan oleh anak didik mereka. Cara yang paling ampuh ialah latihan dan penerangan berterusan supaya murid tidak mudah lupa pelajaran yang diajar. Dalam kurikulum bahasa Melayu sendiri, pengajaran imbuhan sudah mula ditekankan seawal tahun 1. Oleh itu, pada tahap ini, murid-murid ini sebenarnya boleh didedahkan dengan konsep imbuhan yang mudah secara bertahap agar mereka senang memahami proses pengimbuhan yang betul. Contohnya, guru boleh mengajar varian pertama imbuhan meN- dan terangkan sebab-sebab sesuatu huruf dalam kata dasar ada yang melalui proses peluluhan. Pengajaran pada hari tersebut boleh dikaitkan dengan pelajaran pada minggu seterusnya jika guru mahu mengajar varian imbuhan lain yang lebih mudah. Walaupun Dewan Bahasa dan Pustaka (DBP) merupakan badan berwajib yang menyelenggara, menyusun dan membina korpus bahasa Melayu termasuklah usaha-usaha lain untuk memartabatkan bahasa Melayu, tetapi sinergi daripada semua pihak amat penting kerana semua usaha yang dilakukan oleh DBP akan menjadi sia-sia jika masyarakat terus dengan perspektif mempelajari bahasa Melayu hanya untuk lulus dalam peperiksaan.

\section{KESIMPULAN}

Dapatan kajian menunjukkan bahawa murid-murid masih bermasalah dalam penguasaan imbuhan. Pengimbuhan yang diperhatikan adalah melibatkan awalan kata kerja. Hal ini boleh menjadi indikator bahawa tidak mustahil murid turut bermasalah dalam pengimbuhan yang melibatkan kata nama dan kata adjektif, apatah lagi imbuhan yang lebih kompleks yang melibatkan apitan. Kekeliruan pengimbuhan mudah terjadi untuk imbuhan meNyang mempunyai empat varian. Apabila melibatkan perubahan varian yang bergantung pada huruf pertama kata dasar yang mahu diimbuhkan dengan varian $m e N-$, keadaan ini akan menimbulkan masalah kepada murid yang tidak mengetahui rumus perubahan yang dimaksudkan. Oleh itu, tidak mustahil berlaku penggabungan varian morfem meN- mengikut pertimbangan murid sendiri yang difikirkan betul. Signifikannya, kajian yang dijalankan ini diharapkan dapat memberikan kesedaran kepada pihakpihak yang terlibat secara langsung dalam dunia pendidikan khususnya aspek kebahasaan agar terus menitikberatkan kelestarian bahasa Melayu. Sekiranya generasi muda ini tidak mementingkan penggunaan bahasa 
Melayu yang betul, kelak mereka akan semakin memandang remeh martabat bahasa Melayu sebagai bahasa ilmu dan bahasa rasmi negara. Keadaan inilah yang mewujudkan fenomena pelanggaran nahu bahasa Melayu sesuka hati walaupun murid telah melalui tempoh pembelajaran yang panjang. Akhirnya, sikap acuh tidak acuh terhadap bahasa Melayu akan semakin sukar untuk dibendung.

\section{RUJUKAN}

Agustina Putri Reistanti. (2017). Analisis kesalahan berbahasa pada penulisan cerita fabel oleh Siswa Kelas VIII E di SMP 2 Muhammadiyah Surakarta. Kajian Linguistik dan Sastra, 2(2), 126-140.

Ahmed Hafizainol Ahmed Adris \& Karim Harun. (2020). Penguasaan bahasa Melayu sebagai bahasa kedua dalam kalangan pelajar Pondok Bantan Thailand. Jurnal Melayu, Isu Khas Disember, 457-477.

Alhaadi Ismail \& Zaitul Azma Zainon Hamzah. (2018). Analisis kesalahan dalam penulisan pelajar bahasa kedua dari aspek morfologi. Jurnal Linguistik, 22(1), 24-31.

Amirra Shazreena Aminul Razin \& Vijayaletchumy Subramaniam. (2019). Kesalahan penggunaan imbuhan awalan dan akhiran dalam kalangan murid Sekolah Jenis Kebangsaan Tamil berdasarkan Teori Analisis Kesalahan Corder (1973). International Journal of the Malay World and Civilisation, 7(1), 3-13.

Ang, L.H., \& Che Radiah Mezah. (2012). Masalah penggunaan bahasa Melayu dalam kalangan pelajar etnik Cina di Malaysia. SOSIOHUMANIKA, 5(2), 215-226.

Fazal Mohamed Mohamed Sultan, Junaini Kasdan, Zaharani Ahmad \& Nor Hashimah Jalaluddin. (2010). Struktur kata kerja transitif + lagi dalam kalangan pelajar sekolah menengah. Jurnal Linguistik, 10, 36-47.

Hasmidar Hassan, Mardian Shah Omar \& Puteri Roslina Abdul Wahid. (2018). Kecelaruan morfologi dalam penulisan bahasa Melayu oleh penutur asing. Jurnal Linguistik, 22(2), 20-36.

Hidayah Shafiee, Ahmad Fahmi Mahamood, Abdul Rahman Abdul Manaf, Tengku Kastriafuddin Shah Tengku Yaakob, Abdul Jalil Ramli, Zuraidi Ahmad Mokhdzar, Jamsari Jamaluddin, Maskor Bajuri, \& Mohd Erpi Mohd Ali. (2019). Pengaruh bahasa rojak di media baharu terhadap bahasa kebangsaan. International Journal of Law, Government and Communication, 4(15), 141-153.

Ismail Dahaman. (2017). Canggihnya bahasa Melayu: Sistem pembentukan kata, unsur bergabung tutur bersambung. Kuala Lumpur: Dewan Bahasa dan Pustaka. 
Jaafar Jambi. (2008). Cabaran dan proses pemantapan bahasa Melayu. Jurnal Pengajian Melayu, 19, 68-90.

KPM. (2016). Dokumen Standard Kurikulum dan Pentaksiran Bahasa Melayu Tahun 1. Putrajaya: Bahagian Pembangunan Kurikulum.

KPM. (2018). Dokumen Standard Kurikulum dan Pentaksiran Tingkatan 4 dan 5. Putrajaya: Bahagian Pembangunan Kurikulum.

Mohd Syuhaidi Abu Bakar \& Aliffluqman Mohd Mazzalan. (2018). Aliran pertuturan bahasa rojak dalam kalangan pengguna Facebook di Malaysia. e-Academia Journal, 7(1), 61-71.

Mohd Syuhaidi Abu Bakar \& Nor Audra Dayana binti Dahlan. (2018). Percampuran kod bahasa di dalam Filem: Satu kajian kualitatif terhadap filem J Revolusi (2017). e-Academia Journal, 7(2), 107-121.

Nik Safiah Karim, Farid M. Onn, Hashim Haji Musa \& Abdul Hamid Mahmood. (2015). Tatabahasa Dewan Edisi Ketiga. Kuala Lumpur: Dewan Bahasa dan Pustaka.

Nor Hashimah Jalaluddin \& Adriana Santa Anak Tinggam. (2016). Percampuran kod dalam penulisan karangan bahasa Melayu pelajar Cina: Analisis pragmatik. Jurnal Bahasa,16(1),74-93.

Nor Hashimah Jalaluddin, Junaini Kasdan \& Zaharani Ahmad. (2010). Sosiokognitif pelajar remaja terhadap bahasa Melayu. GEMA Online ${ }^{\mathrm{TM}}$ Journal of Language Studies, 10(3), 67-87.

Nurul Adzwa Ahamad, Nur Farahkhanna Mohd Rusli \& Norfaizah Abdul Jobar. (2020). Analisis kesalahan imbuhan dalam penulisan karangan pelajar dan hubung kait dari segi makna gramatikal. Jurnal Pendidikan Bahasa Melayu, 10(1), 77-90.

Nurul Ain Alizuddin \& Nik Nur Athirah Nik Mohd Arif. (2021). Analisis kesalahan bahasa dalam penulisan bahasa Melayu pelajar antarabangsa. International Social Science and Humanities Journal, 4(1), 113-127.

Nurul Huda Mohd Saad \& Nor Hashimah Jalaluddin. (2020). Imbuhan meN- dengan kata nama konkrit unsur alam: Analisis Teori Relevans. GEMA Online ${ }^{\circledR}$ Journal of Language Studies, 20(3), 136-155.

Paul, D., Noor Aina Dani \& Nalmon Goyi. (2020). Kewujudan bahasa antara dalam kalangan pelajar suku Dusun Tindal. $M A N U, 31(1), 25-50$.

Roksana Bibi Abdullah. (2015). Penyerapan bahasa dalam pertembungan budaya: Kesalingan pinjam meminjam dalam kalangan tiga kelompok masyarakat di Singapura. PENDETA - Jurnal Bahasa dan Sastera Melayu, 6, 137-161.

Siti Rahayu Muhammad \& Sharil Nizam Shari. (2020). Kesalahan tatabahasa bahasa Melayu dari aspek morfologi dalam penulisan karangan murid sekolah rendah. International Social Science and Humanities Journal, 3(2), 77-89. 
Siti Rahimah Mustaffa, Raja Masittah Raja Ariffin \& Normahdiah Sheikh Said. (2014). Kekeliruan jati diri punca bahasa bercampur aduk. Jurnal Bahasa, 14(1), 134-158.

Yong C. C., \& Vijayaletchumy Subramaniam. (2012). Analisis kesilapan dalam pembelajaran bahasa Melayu oleh pelajar asing. Gema Online Journal of Language Studies, 12(2), 667-692.

Zaharani Ahmad \& Teressa Jabar. (2010). Tahap penguasaan bahasa Melayu remaja Malaysia: Analisis aspek tatabahasa. Jurnal Linguistik, 10 (Edisi Khas), 48-62.

ANNE JEFFREY KIHOB ialah pelajar yang sedang menuntut dalam pengajian linguistik Bahasa Melayu (Ph.D) di Universiti Malaysia Sabah (UMS).

SAIDATUL NORNIS HJ MAHALI (Ph.D) ialah Profesor Madya di Pusat Penataran Ilmu dan Bahasa (PPIB), Universiti Malaysia Sabah (UMS). 